\title{
Interactions between nutrients, phytoplankton growth, and microzooplankton grazing in a Gulf of Mexico estuary
}

\author{
Andrew R. Juhl ${ }^{1,2, *}$, Michael C. Murrell ${ }^{1}$ \\ ${ }^{1}$ Gulf Ecology Division, United States Environmental Protection Agency, Office of Research and Development, \\ National Health and Environmental Health Research Laboratory, 1 Sabine Island Drive, Gulf Breeze, Florida 32561, USA \\ ${ }^{2}$ Present address: Lamont-Doherty Earth Observatory, Marine Biology Room 2A, 61 Route 9W, Palisades, New York 10964, USA
}

\begin{abstract}
Dilution grazing experiments were conducted on 9 dates over a 16 mo period in Santa Rosa Sound (Florida, USA) measuring microzooplankton grazing $(\mathrm{m})$ and phytoplankton grossgrowth rates under in situ $\left(\mu_{0}\right)$ and replete $\left(\mu_{n}\right)$ nutrient concentrations. The rates were measured on 4 phytoplankton fractions: bulk, $>5 \mu \mathrm{m},<5 \mu \mathrm{m}$, and cyanobacteria. Many similarities existed among phytoplankton fractions: grazing rates were positively correlated with both $\mu_{0}$ and $\mu_{\mathrm{n}}$, the relationship between $\mu_{0}$ and $m$ was nearly 1:1, and $\mu_{\mathrm{n}}$ always exceeded $m$. The 1:1 relationship between $\mu_{0}$ and $m$ implied that microzooplankton grazing accounted for essentially all in situ phytoplankton growth, allowing no net accumulation under ambient nutrient concentrations. Despite this strong grazing pressure, $\mu_{0}<\mu_{\mathrm{n}}$ for all phytoplankton fractions, indicating persistent nutrient limitation. Because $\mu_{\mathrm{n}}$ always exceeded $m$, additional nutrient influx to the sound would generate a disparity between microzooplankton-grazing and phytoplankton-growth rates, resulting in increased biomass in all phytoplankton fractions. However, grazing would remain a major loss term for phytoplankton such that quantitative prediction of the biomass increase would have to incorporate grazing rates. This study therefore provides a useful example of simultaneous 'top-down' and 'bottom-up' control of phytoplankton biomass. We additionally observed that increased nutrient availability led to greater dominance by larger eukaryotic phytoplankton, due to differences in gross-growth rates between the phytoplankton fractions rather than differential grazing. Grazing rates on and gross-growth rates of cyanobacteria, but not the other phytoplankton fractions, were strongly correlated to temperature.
\end{abstract}

KEY WORDS: Phytoplankton growth · Grazing · Nutrients · Dilution experiments · Pensacola Bay

\section{INTRODUCTION}

Many of the ecological consequences of increased nutrient loading to natural water bodies relate to increased production and accumulation of phytoplankton biomass. For example, high phytoplankton standing stock contributes to decreased water clarity (e.g. Scott 1978, Tilzer 1988, Bricaud et al. 1995), which has ecological consequences (e.g. Orth \& Moore 1983, Kautsky et al. 1986) and affects the public perception of water quality (Michael et al. 1996, Boyle et al. 1998). In stratified estuarine environments, increased phytoplankton biomass can also contribute to the develop- ment of hypoxia, a pervasive environmental problem (National Research Council 2000). A nutrient-limited phytoplankton community should respond to increased nutrient loading by increasing phytoplankton gross-growth rates. Whether the increase in grossgrowth rate leads to higher net growth (and phytoplankton biomass accumulation) depends on phytoplankton-loss rates. While losses of phytoplankton occur by various mechanisms (e.g. sinking, lysis, advection, etc.), grazing losses from small, fast-growing microzooplankton are most likely to keep pace with increased phytoplankton growth. Predicting the response of phytoplankton biomass to changes in 
nutrient loading therefore depends critically on how microzooplankton grazing compensates for changes in phytoplankton gross-growth rates. Interactions with microzooplankton may vary for different components of the phytoplankton community and under different environmental conditions. We examined interactions between phytoplankton and microzooplankton in Santa Rosa Sound, a sub-estuary of Pensacola Bay (Florida, USA) from these perspectives.

A previous study of microzooplankton grazing in Pensacola Bay found that, while grazing rates $(m)$ were positively correlated with nutrient-replete phytoplankton gross-growth rates $\left(\mu_{\mathrm{n}}\right), \mu_{\mathrm{n}}$ substantially exceeded $m$, a common finding (Murrell et al. 2002). The practice of amending the treatments of dilution-grazing experiments with nutrients is often necessary to properly estimate grazing rates, but can cause in situ phytoplankton gross-growth rates $\left(\mu_{0}\right)$ to be overestimated (see Landry et al. 1995). In the present study, we included nutrient-amended and unamended treatments to better estimate phytoplankton in situ grossgrowth rates, their relationship with grazing rates, and to examine the effects of nutrient pulses on phytoplankton growth. These analyses were conducted for different phytoplankton groups and were repeated over a range of environmental conditions. Our study therefore compares $\mu_{0}, \mu_{\mathrm{n}}$, and $m$ for different phytoplankton groups to each other and to environmental variables.

\section{MATERIALS AND METHODS}

Study location. Pensacola Bay is an estuary located along the US Gulf of Mexico coast $\left(30^{\circ} 30^{\prime} \mathrm{N}, 87^{\circ} \mathrm{W}\right.$, Fig. 1a). Its shallow depth (mean depth approximately $2 \mathrm{~m}$, Olinger et al. 1975), relatively low turbidity, and low latitude combine to create a high-light environment, where light limitation of phytoplankton growth is rare compared to more commonly studied temperate estuaries (e.g. Cloern 1987, Pennock \& Sharp 1994). Nutrient-addition experiments indicate that phytoplankton growth in Pensacola Bay is generally nutrient-limited (Murrell et al. 2002). This study was focused on Santa Rosa Sound, in the lower portion of the estuary (Fig. 1b).

Dilution experiments. Dilution grazing experiments were conducted on 9 dates from June 2001 to October 2002. Sample water was collected at $1 \mathrm{~m}$ below the surface from a dock at the US Environmental Protection Agency's Gulf Ecology Division Laboratory using an acrylic Alpha sampling bottle
(Wildco). Collections were always made in the morning, usually between 09:00 and 10:00 h, well before peak daily irradiance. Temperature (mercury thermometer) and salinity (refractometer) were measured, and the water was screened through a $375 \mu \mathrm{m}$ nylon mesh to remove larger zooplankton. Qualitative microscopic observations indicated that the potential grazers passing through the mesh included single-celled heterotrophs (heterotrophic nanoflagellates, dinoflagellates, ciliates) and metazoan larvae (polychaete trocophores, copepod nauplii, barnacle cyprids, mollusk veligers, decapod zoea). Water samples were also filtered (Millipore HA) for later analysis of extracted chl a (Strickland \& Parsons 1972). Additional samples were filtered (Whatman GF/F) and frozen for major nutrient analyses, including $\mathrm{NH}_{4}{ }^{+}, \mathrm{NO}_{2}{ }^{-}, \mathrm{NO}_{3}{ }^{-}, \mathrm{PO}_{4}{ }^{3-}$, and $\mathrm{SiO}_{3}$, using standard methods (APHA 1989). Dissolved inorganic nitrogen (DIN) was calculated as the sum of separate analyses for $\mathrm{NO}_{2}{ }^{-}+\mathrm{NO}_{3}{ }^{-}$and $\mathrm{NH}_{4}{ }^{+}$.
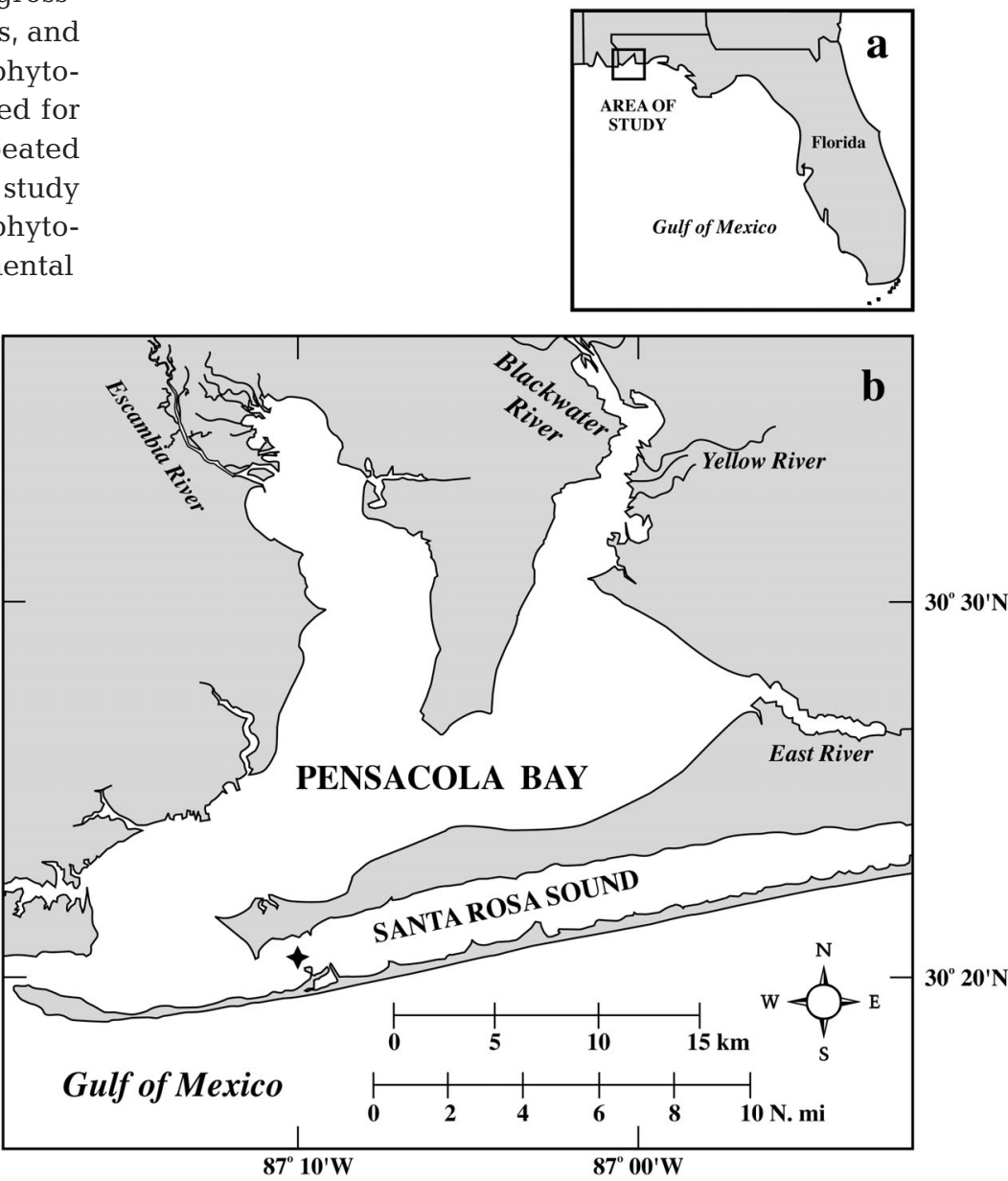

Fig. 1. Map showing study location. (a) Location of Pensacola Bay system in Florida. (b) Santa Rosa Sound as a component of Pensacola Bay.

$\downarrow$ : indicates the approximate location within the sound where samples were collected 
Following Landry et al. (1995), we used a nutrientamended dilution series plus a non-amended wholewater treatment; the dilution treatments included $10,25,50$, and $100 \%$ whole water. Dilution water was made by passing through $0.45 \mu \mathrm{m}$ filters (Millipore HA). Each treatment had 2 replicates, except for the final date, which had 3 . The experimental containers were acid-washed $(10 \% \mathrm{HCl}), 500 \mathrm{ml}$ polycarbonate flasks. Nutrients were added at $16 \mu \mathrm{M} \mathrm{N}\left(8 \mu \mathrm{M} \mathrm{NO}_{3}{ }^{-}\right.$, $\left.8 \mu \mathrm{M} \mathrm{NH}_{4}{ }^{+}\right), 2 \mu \mathrm{M} \mathrm{PO}_{4}{ }^{3-}$, and a mixed trace metal solution (containing $\mathrm{Fe}^{3+}, \mathrm{Cu}^{2+}, \mathrm{MoO}_{4}{ }^{2-}, \mathrm{Zn}^{2+}, \mathrm{Co}^{2+}, \mathrm{Mn}^{2+}$, $\mathrm{SeO}_{3}{ }^{2-}, \mathrm{Ni}^{2+}, \mathrm{VO}_{4}{ }^{3-}$, and $\mathrm{CrO}_{4}{ }^{2-}$, chelated with EDTA). Final trace metal/EDTA concentrations were $10 \%$ of L1 medium concentrations (Guillard \& Hargraves 1993). The experiments were conducted in a laboratory incubator set to ambient temperature and illuminated by cool-white fluorescent lights on a $14 \mathrm{~h}$ light:10 $\mathrm{h}$ dark cycle providing photosynthetically active radiation at ca. $250 \mu \mathrm{mol}$ photons $\mathrm{m}^{-2} \mathrm{~s}^{-1}$. This light level approximated the yearly mean of daily photon flux at $1 \mathrm{~m}$ in Santa Rosa Sound (US EPA Gulf Ecology Division Laboratory unpubl. data), and was also likely saturating, or near saturating, for the growth of most phytoplankton. The objective was to provide illumination such that light neither limited nor inhibited phytoplankton gross growth, rather than matching illumination on a particular day. During incubations, flasks were mixed once or twice daily by gentle inversion, then bottle positions were rearranged to even out minor illumination differences.

Phytoplankton net growth during incubations was measured by changes in biomass over a $2 \mathrm{~d}$ incubation period using either in vivo chlorophyll fluorescence (bulk, $>5 \mu \mathrm{m},<5 \mu \mathrm{m}$ ) or cell abundances (cyanobacteria). In vivo chlorophyll fluorescence (hereafter 'fluorescence') was measured on Days 0, 1, and 2, and cyanobacterial abundances were measured on Days 0 and 2 . While a portion of the $<5 \mu \mathrm{m}$ fraction fluorescence came from cyanobacteria, we think the contribution of cyanobacterial fluorescence was relatively minor, because the fluorescence yield of cyanobacteria is lower than that of eukaryotic algae (Yentsch \& Phinney $1985 a$, b, see below).

Prior to fluorescence measurements, samples were dark-adapted to reduce fluorescence variability associated with prior light history. Initial samples were darkadapted for $2 \mathrm{~h}$, and later time points for $0.5 \mathrm{~h}$. Fluorescence values were not affected by longer darkadaptation periods. To measure fluorescence, each flask was gently inverted to mix and a ca. $30 \mathrm{ml}$ subsample was poured into a $25 \mathrm{~mm}$ diameter cuvette. Fluorescence was measured on a Turner 10 AU fluorometer equipped with a 10-037 optical kit (excitation 340 to $500 \mathrm{~nm}$, emission > $665 \mathrm{~nm}$ ), and re-measured after passing samples through a $5 \mu \mathrm{m}$ pore polycarbon- ate filter (Millipore TMTP). Fluorescence of the $>5 \mu \mathrm{m}$ fraction was calculated by difference. Fluorescence blanks were prepared with $0.45 \mu \mathrm{m}$ filtered sample water and subtracted from all fluorescence measurements. To scale fluorescence to chl a units, a subset of samples was filtered and extracted for chl $a$ analysis (Strickland \& Parsons 1972). These samples were selected to represent the range of fluorescence values measured during the study and included samples from the bulk, $>5 \mu \mathrm{m}$, and $<5 \mu \mathrm{m}$ fractions.

For cyanobacterial abundances, samples were preserved with $2 \%$ formaldehyde and counted following standard bacterial preparation methods (Hobbie et al. 1977) using a Nikon Microphot epifluorescence microscope with green excitation (510 to $560 \mathrm{~nm}$ ) and red emission (>590 nm) filter sets (see Murrell \& Lores 2004). When examined under blue excitation (450 to $490 \mathrm{~nm}$ excitation, $>515 \mathrm{~nm}$ emission) using a filter set combination comparable to that used in the fluorometer, most cyanobacteria were only dimly fluorescent.

Calculation of $\mu_{0}, \mu_{\mathrm{n}}$, and $m$ followed Landry et al. (1995). Theoretically, increased dilution decreases predation mortality of phytoplankton $(m)$, but does not affect their gross-growth rates $\left(\mu_{\mathrm{n}}\right)$. Phytoplankton netgrowth rate for each fraction in each bottle was calculated as the slope of the natural log of biomass (fluorescence or cell abundance) versus time. Net-growth rates for each fraction were plotted as a function of dilution treatment, with each bottle considered an independent replicate. The regression slope of netgrowth rate versus dilution provided $m$ for each fraction (i.e. the decline in net growth in less-dilute samples). Grazing rates were not corrected for potential microzooplankton growth during incubations (Gallegos 1989). The regression intercept provided $\mu_{n}$ (i.e. nutrient-replete growth rate with no predation mortality). When the regressions were non-significant or yielded a positive slope, grazing rate was set to zero and $\mu_{\mathrm{n}}$ was calculated as the mean of all nutrientamended treatments (a significant positive slope was found only once, for the bulk fraction on 27 February 2002). The sum of the grazing rate, $m$, and the mean of net-growth rates in unamended treatments provided $\mu_{0}$ (i.e. growth rate in unamended treatments if there was no predation mortality).

Cyanobacterial fluorescence yield. To estimate the contribution of cyanobacteria to fluorescence, the relative fluorescence yield per cell was determined using cyanobacterial cultures isolated from Pensacola Bay. Two cyanobacterial strains were isolated via enrichment and serial dilution and maintained in $\mathrm{S} / \mathrm{N}$ medium as described in Murrell \& Lores (2004). Both strains were small (1 to $2 \mu \mathrm{m}$ ), unicellular, and coccoid to rod-shaped, similar to open-ocean Synechococcus spp. and the majority of cyanobacteria microscopically 
observed in Pensacola Bay water samples. Three replicate cultures of each strain were grown in $500 \mathrm{ml}$ Pyrex Erlenmeyer flasks in an incubator at $25^{\circ} \mathrm{C}$. The cellspecific fluorescence yield and chl a content of the cultures were measured during exponential growth by simultaneous measurements of fluorescence, extracted chl $a$, and cell concentration.

\section{RESULTS}

Dates and environmental conditions of dilution experiments are shown in Table 1. Ranges in temperature $\left(12\right.$ to $\left.30^{\circ} \mathrm{C}\right)$ and salinity (19 to $\left.27 \mathrm{psu}\right)$ were typical for the lower part of this estuary. Nutrient concentrations were also typical for the lower estuary. DIN averaged $4.4 \mu \mathrm{M}$ and was mostly in the form of ammonium (average $89 \%$ of DIN). $\mathrm{PO}_{4}{ }^{3-}$ concentrations were low, averaging $0.08 \mu \mathrm{M}$. Silica concentrations were relatively high, averaging $18.2 \mu \mathrm{M}$ over the study. Chl $a$ analyses were performed on a subset of 45 samples and regressed against in vivo fluorescence using a Model II geometric-mean regression; based on this regression $\left(r^{2}=0.82\right)$, bulk chl a during this study ranged from ca. 1.3 to $6.9 \mathrm{\mu g} \mathrm{l}^{-1}$, well within the range observed in other studies of Pensacola Bay (Olinger et al. 1975, Murrell \& Lores 2004, J. Macauley unpubl. data). Both size classes $(>5 \mu \mathrm{m},<5 \mu \mathrm{m})$ contributed substantially to bulk fluorescence, with the $<5 \mu \mathrm{m}$ fraction generally accounting for $40 \%$ to $60 \%$ of the total.

Both strains of cultured cyanobacteria had similar cell-specific fluorescence and extracted chl $a$, so the data were combined. Cyanobacteria contained $3.1 \pm$ $0.1 \mathrm{fg}$ chl $a$ cell $^{-1}( \pm 1 \mathrm{SE}, \mathrm{n}=6$ ), comparable to oceanic Synechococcus spp. (Kana \& Glibert 1987, Moore et al. 1995) and similar to a value of $3.4 \mathrm{fg} \mathrm{chl} \mathrm{a} \mathrm{cell}{ }^{-1}$ derived empirically from Pensacola Bay (Murrell \& Lores 2004).
The ratio of fluorescence to chl a concentration averaged 0.08 , and was much lower than the mean ratios of from 0.4 to 0.6 observed for the other phytoplankton fractions (Table 2). This suggests that fluorescence was largely attributable to eukaryotic algae, as were the growth and grazing rates derived from fluorescence measurements.

Results of dilution experiments showed that most dates and fractions yielded statistically significant regressions (Table 3). All phytoplankton fractions had similar ranges for growth and grazing rates. Pooling the data together: $\mu_{0}$ ranged from -0.2 to $1.9 \mathrm{~d}^{-1}, \mu_{\mathrm{n}}$ ranged from 0 to $2.1 \mathrm{~d}^{-1}$, and $m$ ranged from 0 to $1.7 \mathrm{~d}^{-1}$. The $>5 \mu \mathrm{m}$ fraction had higher mean values for growth $\left(\mu_{0}\right.$ and $\left.\mu_{\mathrm{n}}\right)$ and grazing $(m)$ rates than the $<5 \mu \mathrm{m}$ and cyanobacterial fractions, but their ranges overlapped on different dates. To examine whether patterns of growth rates were consistent between dates, we used an analysis of variance (ANOVA) that treated date as a blocking factor, while presence $\left(\mu_{n}\right)$ or absence $\left(\mu_{0}\right)$ of nutrient addition and phytoplankton fraction were both fixed effects. Because of overlap

Table 2. Ratios of in vivo fluorescence per unit extracted chl a of natural phytoplankton communities and cultured cyanobacteria isolated from Pensacola Bay. Bulk, $>5 \mu \mathrm{m}$, and $<5 \mu \mathrm{m}$ size fractions had higher fluorescence yield than the cyanobacterial cultures, suggesting that in vivo fluorescence of natural samples is predominately due to eukaryotic phytoplankton

\begin{tabular}{|lcccc|}
\hline & Mean & SD & Range & N \\
\hline Bulk & 0.41 & 0.14 & $0.20-0.63$ & 27 \\
$>5 \mu \mathrm{m}$ & 0.60 & 0.32 & $0.25-1.05$ & 5 \\
$<5 \mu \mathrm{m}$ & 0.37 & 0.22 & $0.15-0.83$ & 13 \\
Cyanobacterial culture & 0.08 & 0.006 & $0.07-0.09$ & 6 \\
\hline
\end{tabular}

Table 1. Summary of environmental conditions during study (DIN: dissolved inorganic nitrogen; bulk fluorescence: darkadapted, in vivo chlorophyll fluorescence; percent fluorescence $<5 \mu \mathrm{m}$ : the percent of bulk fluorescence that passed a $5 \mu \mathrm{m}$ filter; bulk chl a: estimated from a calibration of fluorescence to extracted chl a)

\begin{tabular}{|c|c|c|c|c|c|c|c|c|c|}
\hline Date & $\begin{array}{l}\text { Temp. } \\
\left({ }^{\circ} \mathrm{C}\right)\end{array}$ & $\begin{array}{l}\text { Salinity } \\
\text { (psu) }\end{array}$ & $\begin{array}{l}\text { DIN } \\
(\mu \mathrm{M})\end{array}$ & $\begin{array}{l}\mathrm{PO}_{4}^{3-} \\
(\mu \mathrm{M})\end{array}$ & $\begin{array}{l}\mathrm{SiO}_{3} \\
(\mu \mathrm{M})\end{array}$ & $\begin{array}{c}\text { Bulk } \\
\text { fluorescence }\end{array}$ & $\begin{array}{c}\% \text { fluorescence } \\
<5 \mu \mathrm{M}\end{array}$ & $\begin{array}{c}\text { Bulk } \\
\text { chl a } \\
\left(\mu \mathrm{g} \mathrm{l}^{-1}\right)\end{array}$ & $\begin{array}{c}\text { Cyanobacterial } \\
\text { concentration } \\
\left(10^{9} \mathrm{l}^{-1}\right)\end{array}$ \\
\hline 7 Jun 01 & 28 & 27 & - & 0.13 & 5.8 & 1.7 & 49 & 5.4 & - \\
\hline 5 Jul 01 & 30 & 21 & 3.3 & 0.05 & 37.2 & 1.2 & 55 & 3.3 & - \\
\hline 1 Aug 01 & 29 & 24 & - & 0.09 & 13.9 & 2.1 & 39 & 6.9 & 0.40 \\
\hline 29 Aug 01 & 30 & 19 & 3.9 & 0.15 & 33.6 & 1.8 & 72 & 5.5 & 2.49 \\
\hline 17 Oct 01 & 21 & 24 & 3.0 & 0.02 & 27.7 & 1.6 & 55 & 4.7 & 0.73 \\
\hline 28 Nov 01 & 22 & 27 & 1.9 & 0.07 & 11.5 & 0.8 & 47 & 1.3 & 0.27 \\
\hline 27 Feb 02 & 12 & 25 & 7.5 & 0.06 & 13.1 & 1.2 & 47 & 3.2 & 0.21 \\
\hline 16 Apr 02 & 23 & 24 & 6.8 & 0.07 & 2.8 & 1.5 & 16 & 4.3 & 0.06 \\
\hline 8 Oct 02 & 28 & 20 & - & - & - & 1.3 & 58 & 3.6 & 0.51 \\
\hline Mean & 25 & 23 & 4.4 & 0.08 & 18.2 & 1.5 & 49 & 4.2 & 0.67 \\
\hline
\end{tabular}


between the $<5 \mu \mathrm{m}$ and cyanobacterial fractions, separate analyses were performed on pairs of independent fractions, namely $>5 \mu \mathrm{m}$ versus $<5 \mu \mathrm{m}$ and $>5 \mu \mathrm{m}$ versus cyanobacteria. F-values for these 3-way, mixedmodel ANOVAs were calculated according to Zar (1974, Appendix C). In both cases, nutrients and phytoplankton fraction had significant effects on growth rates ( $p<0.008$ in each case), with insignificant interaction between the 2 ( $p>0.1$ in each case). The stimulatory effect of nutrient addition was obvious, as $\mu_{n}$ always exceeded $\mu_{0}$ on a given date (Table 3 ), the effect of the phytoplankton fraction was more subtle. Only when variability among dates was factored out was it evident that the $>5 \mu \mathrm{m}$ fraction had higher growth rates (for both $\mu_{0}$ and $\mu_{n}$ ) than the $<5 \mu$ m or cyanobacterial fractions.

Grazing rates were examined in a similar way using a 2-way ANOVA, with phytoplankton fraction as the main effect and date as a blocking factor. Grazing rate was significantly higher on the $>5 \mu \mathrm{m}$ fraction than on the $<5 \mu \mathrm{m}$ fraction $\left(F_{1,8}=6.189, \mathrm{p}=0.038\right)$, but did not differ significantly between the $>5 \mu \mathrm{m}$ and cyanobacterial fractions $\left(F_{1,6}=3.522, \mathrm{p}=0.11\right)$.

For all phytoplankton fractions, a significant positive relationship was found between $m$ and the corresponding $\mu_{0}$ value ( $\mathrm{p}<0.0012$ for each comparison). The relationship between $m$ and $\mu_{0}$ was nearly $1: 1$ when all phytoplankton groups were included (Fig. 2a). Significant positive correlations were also found between $m$ and $\mu_{n}$ for each phytoplankton fraction ( $\mathrm{p} \leq 0.05$ for each comparison). However, the relationships between $m$ and $\mu_{n}$ were generally weaker than between $m$ and $\mu_{0}$. A trendline fit to data pooled from all fractions showed a slope of 0.76 (Fig. 2b).

The degree of phytoplankton-growth stimulation due to nutrient additions $\left(\mu_{n}-\mu_{0}\right)$ was examined for the various fractions as a function of the in situ phytoplankton-growth rate (Fig. 3). All values of $\mu_{n}-\mu_{0}$ were $>0$, illustrating that nutrients always stimulated phytoplankton growth (by from 0.1 to $1.7 \mathrm{~d}^{-1}$ ) over in situ rates. Nutrient addition had a larger, but more variable, stimulatory effect at low in situ phytoplanktongrowth rates $\left(\mu_{0}\right)$.

We examined how environmental variables (initial phytoplankton biomass, temperature, salinity) related to growth- and grazing-rate estimates (Table 4). Phytoplankton biomass tended to be positively related to growth and grazing rates, but statistically significant correlations were only found for the bulk fraction. Temperature was strongly correlated to cyanobacterial growth and grazing rates, but was not significantly correlated for other fractions. Salinity was negatively related to all growth and grazing rates, but the correlations were only statistically significant for the cyanobacterial fraction. Across all size fractions, growth and grazing rates were more strongly correlated to each other than they were to environmental parameters. The exception to this was the apparent temperature effect on cyanobacterial growth and grazing rates.

\section{DISCUSSION}

A nutrient pulse to Santa Rosa Sound would likely be followed by a rapid increase in phytoplankton grossgrowth rate. Although we found no evidence that grazing could compensate for increases in phytoplankton gross-growth rate, grazing always represented a major loss term for the phytoplankton. Quantitatively predicting the response of phytoplankton biomass to nutrient availability would not be possible without taking grazing into account.

Table 3. Summary of specific growth $\left(\mu_{0}\right.$ : in situ phytoplankton gross-growth rates; $\mu_{\mathrm{n}}$ : nutrient-replete phytoplankton grossgrowth rates) and grazing $(m)$ parameters $\left(\mathrm{d}^{-1}\right)$ and the $\mathrm{r}^{2}$ of the individual regressions of net growth versus dilution for the various phytoplankton fractions. Asterisks indicate statistically significant regressions at $\mathrm{p}<0.05$. If not significant, or the slope was positive, grazing was set to zero and $\mu_{\mathrm{n}}$ was calculated as the mean net growth rate of all nutrient-amended treatments

\begin{tabular}{|c|c|c|c|c|c|c|c|c|c|c|c|c|c|c|c|c|}
\hline \multirow[t]{2}{*}{ Date } & \multicolumn{4}{|c|}{$\longrightarrow$ Bulk } & \multicolumn{4}{|c|}{$\longrightarrow$ > } & \multicolumn{4}{|c|}{$-<5 \mu \mathrm{m}$} & \multicolumn{4}{|c|}{ - Cyanobacteria } \\
\hline & $\mu_{0}$ & $\mu_{\mathrm{n}}$ & $m$ & $\mathrm{r}^{2}$ & $\mu_{0}$ & $\mu_{\mathrm{n}}$ & $m$ & $\mathrm{r}^{2}$ & $\mu_{0}$ & $\mu_{\mathrm{n}}$ & $m$ & $\mathrm{r}^{2}$ & $\mu_{0}$ & $\mu_{\mathrm{n}}$ & $m$ & $\mathrm{r}^{2}$ \\
\hline 7 Jun 01 & 0.7 & 1.5 & 0.8 & $0.98^{*}$ & 0.6 & 1.6 & 0.7 & $0.92^{*}$ & 0.8 & 1.3 & 0.8 & $0.95^{*}$ & - & - & - & - \\
\hline 5 Jul 01 & 0.3 & 1.1 & 0.2 & $0.69^{*}$ & 0.2 & 1.2 & 0.0 & 0.22 & -0.1 & 0.6 & 0.0 & $0.41^{*}$ & - & - & - & - \\
\hline 2 Aug 01 & 1.8 & 2.1 & 1.5 & $0.95^{*}$ & 1.9 & 2.3 & 1.7 & $0.95^{*}$ & 1.3 & 1.6 & 1.2 & $0.78^{*}$ & 0.8 & 1.3 & 0.5 & $0.72^{*}$ \\
\hline 29 Aug 01 & 1.1 & 1.4 & 1.2 & $0.90^{*}$ & 1.2 & 1.7 & 1.4 & $0.95^{*}$ & 1.0 & 1.3 & 1.1 & $0.86^{*}$ & 1.2 & 1.4 & 1.3 & $0.94^{*}$ \\
\hline 17 Oct 01 & 0.4 & 1.4 & 0.5 & $0.97^{*}$ & 0.6 & 1.8 & 0.6 & $0.81^{*}$ & 0.4 & 1.2 & 0.4 & $0.92^{*}$ & 0.4 & 0.9 & 0.6 & $0.62^{*}$ \\
\hline 28 Nov 01 & -0.1 & 1.2 & 0.0 & 0.21 & -0.2 & 1.4 & 0.0 & 0.23 & -0.1 & 1.1 & 0.0 & 0.00 & 0.4 & 0.7 & 0.4 & $0.85^{*}$ \\
\hline 27 Feb 02 & 0.1 & 0.5 & 0.0 & - & 0.3 & 0.6 & 0.0 & 0.37 & -0.1 & 0.1 & 0.0 & $0.50^{*}$ & 0.0 & 0.0 & 0.0 & 0.03 \\
\hline 16 Apr 02 & 1.4 & 2.1 & 1.3 & $0.85^{*}$ & 1.4 & 2.1 & 1.4 & $0.85^{*}$ & 1.1 & 2.0 & 1.2 & $0.82^{*}$ & 0.7 & 1.0 & 0.8 & $0.92^{*}$ \\
\hline 8 Oct 02 & 1.2 & 1.8 & 1.2 & $0.96^{*}$ & 1.4 & 2.0 & 1.3 & $0.94^{*}$ & 0.9 & 1.6 & 1.2 & $0.98^{*}$ & 0.9 & 1.8 & 0.8 & $0.98^{*}$ \\
\hline Mean & 0.8 & 1.5 & 0.8 & & 0.8 & 1.6 & 0.8 & & 0.6 & 1.2 & 0.7 & & & 0.6 & 1.0 & 0.6 \\
\hline SD & 0.6 & 0.5 & 0.6 & & 0.7 & 0.5 & 0.7 & & 0.6 & 0.6 & 0.6 & & & 0.4 & 0.6 & 0.4 \\
\hline
\end{tabular}



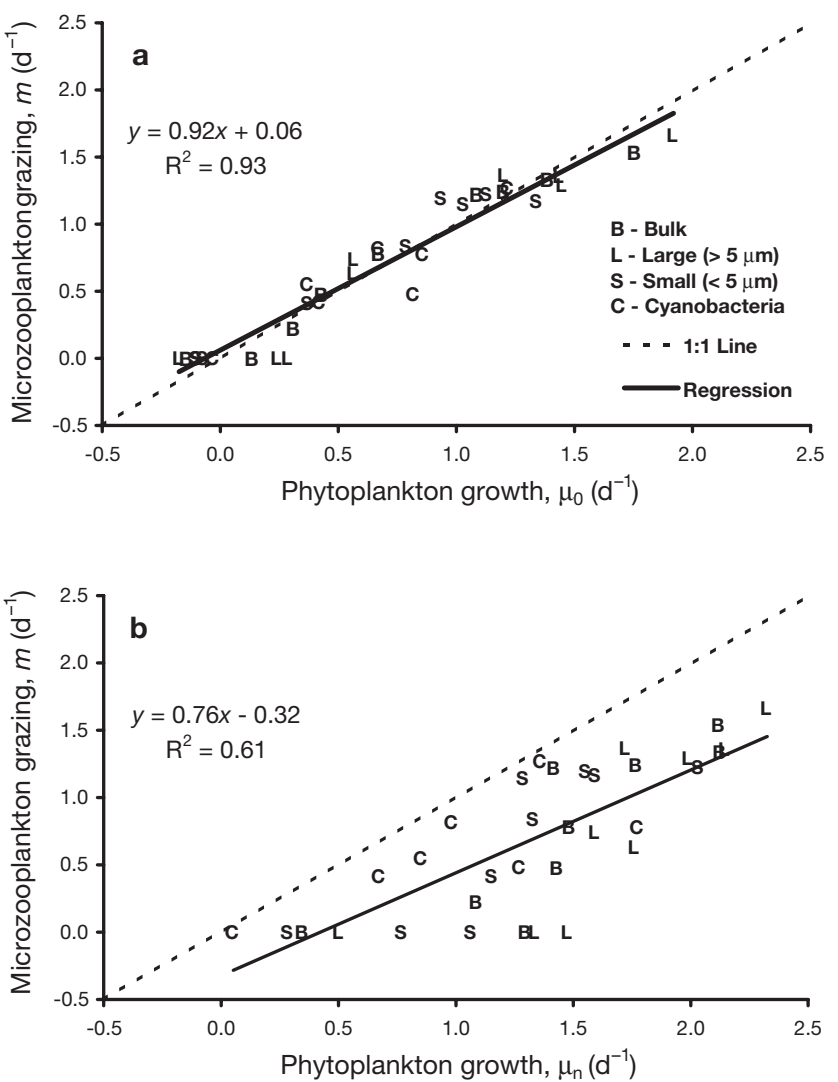

Fig. 2. Relationship between phytoplankton gross-growth and microzooplankton grazing rates. (a) Gross-growth rate at in situ nutrient concentration $\left(\mu_{0}\right)$ versus $m$. (b) Nutrient-replete gross-growth rate $\left(\mu_{n}\right)$ versus $m$. Letter symbols represent different phytoplankton groups. The regression line and equation provided resulted from an analysis of pooled data. The 1:1 line indicates an exact match between the 2 rates

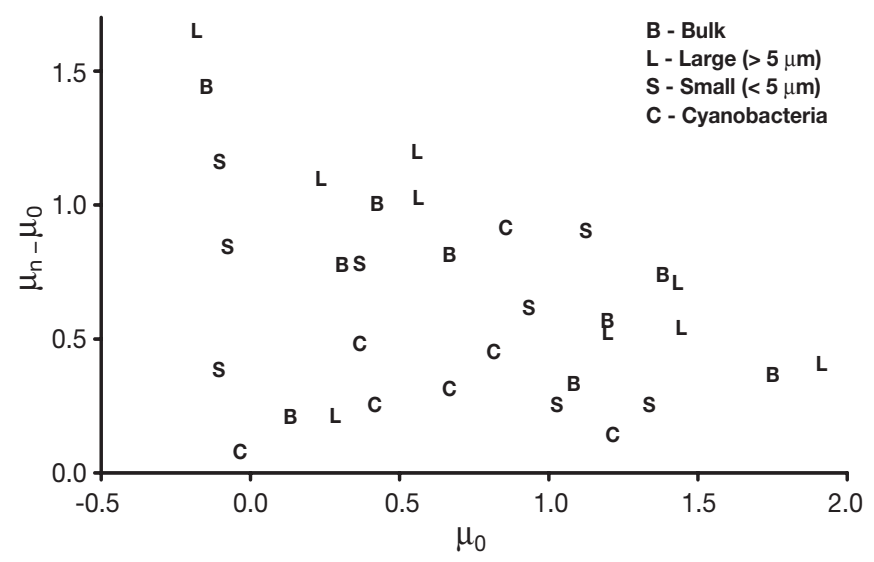

Fig. 3. Net stimulation of phytoplankton growth rate $\left(\mu_{n}-\mu_{0}\right)$ caused by nutrient addition as a function of in situ phytoplankton growth. Letter symbols represent different phytoplankton groups. The greatest differences in growth rates occurred when in situ phytoplankton-growth rates $\left(\mu_{0}\right)$ were low
Table 4. Pearson correlation coefficients of environmental variables versus growth and grazing rates for the various fractions. Biomass was measured by in vivo chlorophyll fluorescence (bulk, $>5 \mu \mathrm{m},<5 \mu \mathrm{m}$ ) or cell concentration (cyanobacteria: cyano). ${ }^{*}: \mathrm{p}<0.05 ;{ }^{* *}: \mathrm{p}<0.01$

\begin{tabular}{|lclcc}
\hline Parameter & Fraction & $\mu_{0}$ & $\mu_{\mathrm{n}}$ & $m$ \\
\hline Biomass & Bulk & $0.76^{*}$ & 0.50 & $0.74^{*}$ \\
& $>5 \mu \mathrm{m}$ & 0.65 & 0.55 & 0.59 \\
& $<5 \mu \mathrm{m}$ & 0.32 & -0.03 & 0.31 \\
& Cyano & 0.66 & 0.37 & 0.73 \\
Temp. & Bulk & 0.51 & 0.57 & 0.57 \\
& $>5 \mu \mathrm{m}$ & 0.44 & 0.63 & 0.50 \\
& $<5 \mu \mathrm{m}$ & 0.53 & 0.57 & 0.52 \\
Salinity & Cyano & $0.95^{* *}$ & $0.93^{* *}$ & $0.78^{*}$ \\
& Bulk & -0.38 & -0.11 & -0.40 \\
& $>5 \mu \mathrm{m}$ & -0.43 & -0.21 & -0.38 \\
& $<5 \mu \mathrm{m}$ & -0.28 & -0.13 & -0.36 \\
& Cyano & $-0.76^{*}$ & -0.73 & $-0.76^{*}$ \\
& & & & \\
& & & & \\
& & &
\end{tabular}

\section{Grazing and nutrient control of phytoplankton biomass}

We observed a strong relationship between phytoplankton-growth (both in situ and nutrient-amended) and microzooplankton-grazing rates (Fig. 2, Table 5). Numerous studies, which together span a broad trophic gradient from estuarine to open-ocean environments, have noted similar correlations (see Murrell et al. 2002). However, most studies have found that phytoplankton gross growth exceeds microzooplankton grazing. Intuitively, this makes sense, because microzooplankton grazing is but one of many potential phytoplankton losses (e.g. mesozooplankton grazing, sinking, lysis, advection). In situ phytoplankton growth and microzooplankton grazing were unusually well balanced in Santa Rosa Sound.

The factors controlling phytoplankton biomass are often couched in terms of a top-down versus bottom-up dichotomy. Top-down controls refer to predation, while bottom-up, or resource-limited, controls include light, temperature, etc., but usually refer to nutrients. Our data provide a useful demonstration of why topdown and bottom-up controls should be thought of as complementary, rather than contradictory (Carpenter et al. 1985). In Santa Rosa Sound, phytoplankton grossgrowth rates were generally high under in situ nutrient conditions, but grazing essentially matched new phytoplankton growth. Grazing clearly had a strong effect on phytoplankton biomass, keeping net phytoplankton growth near zero. Taken in isolation, the high grazing rates and lack of positive net growth could argue for top-down control of phytoplankton biomass. However, our data also clearly demonstrate that the phytoplankton were nutrient-limited, as evidenced by 
Table 5. Average values for growth and grazing from the literature $( \pm \mathrm{SD})$. Only studies that measured both in situ and nutrientreplete phytoplankton growth rates were included. Regression statistics examine the relationship of $m$ as a function of $\mu_{0}$, showing the exceptionally strong relationship in Santa Rosa Sound compared to other studies

\begin{tabular}{|c|c|c|c|c|c|c|c|c|}
\hline Location & $\mu_{0}$ & $\mu_{\mathrm{n}}$ & $m$ & Slope & Intercept & $\mathrm{r}^{2}$ & $\mathrm{n}$ & Source \\
\hline Equatorial Pacific & $0.65 \pm 0.42$ & $0.65 \pm 0.38$ & $0.39 \pm 0.34$ & 0.33 & 0.18 & 0.16 & 35 & Landry et al. (1995) ${ }^{\mathrm{a}}$ \\
\hline Gulf of Mexico & $0.40 \pm 0.19$ & $0.99 \pm 0.98$ & $0.24 \pm 0.15$ & -0.38 & 0.39 & 0.22 & 8 & Strom \& Strom (1996) \\
\hline Arabian Sea & $0.72 \pm 0.46$ & $1.03 \pm 0.46$ & $0.56 \pm 0.23$ & 0.26 & 0.37 & 0.26 & 61 & Landry et al. (1998) \\
\hline Arabian Sea & $0.65 \pm 0.33$ & $0.85 \pm 0.32$ & $0.33 \pm 0.18$ & 0.28 & 0.14 & 0.36 & 30 & Caron \& Dennett (1999) \\
\hline Gulf of Mexico & $0.81 \pm 0.45$ & $1.14 \pm 0.57$ & $0.69 \pm 0.42$ & 0.11 & 0.60 & 0.01 & 18 & Liu \& Dagg $(2003)^{\mathrm{b}}$ \\
\hline Santa Rosa Sound & $0.76 \pm 0.63$ & $1.46 \pm 0.55$ & $0.76 \pm 0.60$ & 0.93 & 0.05 & 0.96 & 9 & Present study ${ }^{c}$ \\
\hline
\end{tabular}

the increase of gross-growth rates with nutrient addition. Although growth rates of all phytoplankton groups increased dramatically following nutrient amendment, most new phytoplankton growth was still lost to grazing. Any biomass accumulation was due to a relatively small imbalance between the 2 rates. The balance between top-down and bottom-up controls, rather than one or the other, determined phytoplankton biomass.

\section{Comparisons between phytoplankton fractions}

We found many similarities among rates measured for different phytoplankton fractions. The essentially 1:1 relationship between $\mu_{0}$ and $m$ was comparably strong for the different phytoplankton groups, suggesting that microzooplankton were capable of preventing positive net growth for all components of the phytoplankton community under ambient nutrient conditions. Other studies that have examined sizespecific grazing have also found that microzooplankton have comparable impacts on different phytoplankton fractions (Paranjape 1987, Kamiyama 1994, Strom \& Strom 1996, Froneman \& McQuaid 1997, Liu \& Dagg 2003).

The degree of nutrient limitation also did not vary consistently among phytoplankton groups. However, the $>5 \mu \mathrm{m}$ fraction tended to have the highest, and cyanobacteria tended to have the lowest, nutrientamended growth rates. Several $\mu_{\mathrm{n}}$ values for the $>5 \mu \mathrm{m}$ fraction were near, or exceeded, $2 \mathrm{~d}^{-1}$ (2.9 cell divisions $\mathrm{d}^{-1}$ ). Cyanobacteria-growth rates averaged $1.0 \mathrm{~d}^{-1}$ (1.4 cell divisions $\mathrm{d}^{-1}$ ), although the peak values reached $1.8 \mathrm{~d}^{-1}\left(2.6\right.$ cell divisions $\left.\mathrm{d}^{-1}\right)$. Nevertheless, even peak $\mu_{n}$ values in this study were well below the maximum temperature-dependent growth rates of phytoplankton (Fig. 4). Other compilations of phytoplankton gross-growth rates (Eppley 1972, Banse
1995) have similarly found that measured rates rarely approach the maximum limits defined by Eppley (1972).

After nutrient additions, the new balance between growth and grazing was not equivalent among the different groups. Nutrient addition led to increased dominance by the $>5 \mu \mathrm{m}$ fraction. Periodic microscopic observation of samples collected at the end of the incubation period clearly showed that diatoms became the dominant phytoplankton group following nutrient amendment. Dominance by larger phytoplankton, especially by diatoms, is common in nutrient-rich waters. The observation has been explained (e.g. Kiorboe 1998) as a consequence of low grazing on large phytoplankton due to the comparatively slow reproduction rates of copepods. In contrast, results of this study indicate that eukaryotic algae of the $>5 \mu \mathrm{m}$ fraction experienced grazing rates as high, or higher than, smaller phytoplankton. The shift to larger phytoplankton following increased nutrient availability was related to the high nutrient-replete, gross-growth rates

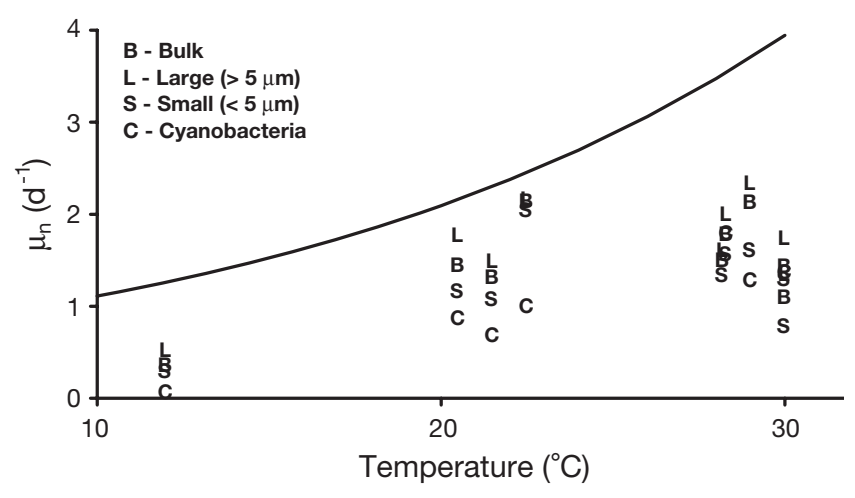

Fig. 4. Relationship between $\mu_{\mathrm{n}}$ and temperature for the different phytoplankton groups. Each group is represented by a different letter. The solid line is the empirically derived, maximum phytoplankton-growth rate as a function of temperature, from Eppley (1972) 
of the $>5 \mu \mathrm{m}$ fraction $\left(\mu_{\mathrm{n}}\right)$, rather than to low grazing pressure. The oft-observed dominance of large diatoms in nutrient-rich waters may have more to do with differential gross-growth rates than with size-selective grazing (see Lonsdale et al. 1996a).

\section{Explaining the close growth and grazing rate relationships}

The strong correlations between phytoplankton gross-growth and microzooplankton grazing could be explained by a close match between growth rates of phytoplankton and microzooplankton. When phytoplankton biomass increases, a rapid numerical response by microzooplankton can compensate, cropping down the excess production (e.g. Frost 1993). However, following this argument, microzooplankton would be predicted to graze phytoplankton down to limiting concentrations, as was suggested in a study in the oligotrophic Sargasso Sea (Lessard \& Murrell 1998). It seems unlikely that phytoplankton concentrations during this study were low enough to support such a scenario.

The connection between growth and grazing rates may actually be indirect. For example, in situ phytoplankton gross-growth rate may be set by the rate of nutrient regeneration by grazers (Banse 1995). Several observations from our study support this mechanism. First, phytoplankton gross-growth rates were consistently nutrient-limited. Second, the high phytoplankton-growth rates measured in Santa Rosa Sound would likely remove available nutrients from the water column if not regenerated through grazing. Third, DIN in Santa Rosa Sound was dominated by ammonium, which could be the product of grazers.

\section{Environmental controls on growth and grazing rates}

Another possible explanation for the growth/grazing rate relationships is that environmental factors, such as temperature or salinity, influenced all 3 variables. This may be the case, particularly for the cyanobacteria. Both $\mu_{0}$ and $\mu_{\mathrm{n}}$ of cyanobacteria, and grazing rates on cyanobacteria, were significantly correlated to temperature. Other studies have found a similarly strong influence of temperature on in situ cyanobacterial growth rate (Carpenter \& Campbell 1988, Moore et al. 1995, Li 1998). While growth and grazing rates for cyanobacterial populations in Santa Rosa Sound can be reasonably well predicted by temperature, temperature was not significantly correlated to eukaryotic phytoplankton-growth rates. It is intriguing, and somewhat counterintuitive, that grazing rates on each phytoplankton fraction were strongly correlated to that fraction's growth rates, but only weakly related to the fraction's biomass.

\section{Potential methodological concerns}

Experiments using bottle incubations need to be carefully interpreted because of various potential artifacts. For example, most microzooplankton grazing studies screen larger zooplankton to reduce the variability caused by uneven capture of relatively rare, large grazers. If the excluded zooplankton feed heavily on microzooplankton, then the total grazing on phytoplankton will be overestimated relative to in situ rates (Lonsdale et al. 1996b, Nejestgaard et al. 2001). Alternatively, if excluded zooplankton are primarily herbivorous, total grazing on phytoplankton may be underestimated. Studies that have examined both microzooplankton and mesozooplankton grazing simultaneously (e.g. Liu \& Dagg 2003), usually find that mesozooplankton contribute little to phytoplankton mortality compared to microzooplankton, but they can be significant grazers of microzooplankton (Lonsdale et al. 1996b, Sipura et al. 2003).

Another important consideration is the incubation time used for dilution experiments. Most researchers incubate dilution experiments for $1 \mathrm{~d}$ rather than the $2 \mathrm{~d}$ incubations used in this study, reasoning that shorter incubation times lead to fewer artifacts and may more accurately represent in situ conditions. We incubated for $2 \mathrm{~d}$, but collected fluorescence readings on Day 1 as well, and thus were able to evaluate the relative quality of 1 and 2 d estimates of net-growth rate within each bottle. While $2 \mathrm{~d}$ rates had a higher median than $1 \mathrm{~d}$ rates (0.92 vs $0.74 \mathrm{~d}^{-1}$, respectively), the difference was not statistically significant (MannWhitney test, $\mathrm{p}=0.32, \mathrm{n}=264$ ). We also compared 1 - and 2-d rates with respect to variability among duplicate bottles, calculated as the percent difference from the mean. Variability in net-growth rate among replicates was higher in 1-d than in 2-d incubations, and this difference was statistically significant (MannWhitney test, $\mathrm{p}=0.001, \mathrm{n}=119$ ). These results suggest that calculated net-growth rates were not especially sensitive to incubation length, but that better replication was achieved with 2 -d incubations. It appeared that the 2-d incubations allowed us to better resolve a growth signal over 1-d incubations, without significantly affecting the net-growth-rate estimates used to calculate $\mu_{0}, \mu_{n}$, and $m$.

One critical assumption of the dilution method is that grazing is a linear function of prey density, but several studies have observed, and accounted for, non-linear grazing kinetics (Gallegos 1989, Evans \& Paranjape 
1992). Saturated grazing should be more prevalent in systems with high phytoplankton biomass. The relatively modest chl a levels we observed in Santa Rosa Sound suggest that grazer saturation was unlikely. Visual inspection of Landry-Hassett plots (Landry \& Hassett 1982) revealed no obvious curvature that would indicate saturated grazing. We examined the linear assumption more formally by testing whether the Landry-Hassett intercept $\left(\mu_{n}\right)$ was different from the net-growth rate of the most dilute treatment $(10 \%$ whole water). The 2 growth rates were not significantly different (paired $t$-tests for each phytoplankton group, p-values exceeded 0.12 in each case). Similar findings were observed in a previous study of microzooplankton grazing in Pensacola Bay (Murrell et al. 2002).

Fluorescence is a commonly used proxy for phytoplankton biomass, although the relationship of fluorescence to chl a (and of chl a to biomass) is variable. To decrease variability in fluorescence:chl $a$ due to light history, we collected subsurface samples in the morning, lowering the likelihood of collecting photoinhibited cells. Samples were also dark-adapted before making fluorescence measurements. Moreover, estimation of growth and grazing rates, our primary objective, was based on relative changes in fluorescence between treatments (for the relevant fractions), and did not require absolute calibration to biomass. Another caveat of fluorescence is a bias against common cyanobacteria. Fluorescence-based growth and grazing rates have, therefore, been taken to represent rates for eukaryotic phytoplankton, while rates for cyanobacteria were estimated separately using direct cell counts.

While experimental artifacts are unavoidable in dilution or other bottle incubation experiments, it is useful to consider their potential effect on the results whenever possible. In the cases above, where it is possible to evaluate them explicitly, the assumptions underlying the dilution method appear well supported. Our application of the method should therefore provide reasonable estimates of microzooplankton grazing and phytoplankton-growth rates.

\section{CONCLUSIONS}

The combination of methods used in this study to measure biomass (size fractionation, fluorescence, cell counts) provided insight into critical rates for several phytoplankton groups in Santa Rosa Sound. The ease and rapidity of sample processing outweighed complications from overlap between groups. Consistent results were found among the phytoplankton groups within experiments and across the range of environmental conditions encountered during the study. While phytoplankton in situ gross-growth rates were usually positive $\left(\mu_{0}>0\right)$ and frequently quite high, phytoplankton in all groups were consistently nutrient-limited $\left(\mu_{\mathrm{n}}>\mu_{0}\right)$. Microzooplankton grazing was a major loss term for all phytoplankton groups, preventing biomass accumulation under ambient nutrient concentrations $\left(\mu_{0} \approx m\right)$. Nutrient-replete phytoplankton gross-growth rates always exceeded grazing rates $\left(\mu_{\mathrm{n}}>m\right)$. Phytoplankton in the $>5 \mu \mathrm{m}$ fraction had the highest $\mu_{\mathrm{n}}$ values. Despite the generally high microzooplankton grazing rates in Santa Rosa Sound, increased nutrient availability would be expected to increase phytoplankton biomass, especially of larger eukaryotic cells. Because phytoplankton biomass is largely determined by the balance between phytoplankton-growth and loss terms, quantifying both rates is necessary to predict the response of estuarine phytoplankton biomass to increased nutrient loading.

Acknowledgements. Comments from R. Greene and 3 anonymous reviewers improved earlier versions of this manuscript. This is Contribution No. 1214 US EPA, Gulf Breeze, FL, USA. Mention of trade names or commercial products does not constitute endorsement by the US EPA.

\section{LITERATURE CITED}

APHA (American Public Health Association) (1989) Standard methods for the examination of water and wastewater, 17th edn. APHA, Washington, DC

Banse K (1995) Zooplankton: pivotal role in the control of ocean production. ICES J Mar Sci 52:265-277

Boyle KJ, Lawson SR, Michael HJ, Bouchard R (1998) Lakefront property owners economic demand for water clarity in Maine lakes. Miscellaneous Report 410. Maine Agricultural and Forest Experimental Station, University of Maine, Walpole, ME

Bricaud A, Babin M, Morel A, Claustre H (1995) Variability in the chlorophyll-specific absorption coefficients of natural phytoplankton: analysis and parameterization. J Geophys Res 100:13321-13332

Caron DA, Dennett MR (1999) Phytoplankton growth and mortality during the 1995 Northeast Monsoon and Spring Intermonsoon in the Arabian Sea. Deep-Sea Res II 46: $1665-1690$

Carpenter EJ, Campbell L (1988) Diel patterns of cell division and growth rates of Synechococcus spp. in Long Island Sound. Mar Ecol Prog Ser 47:179-183

Carpenter SR, Kitchell JF, Hodgson JR (1985) Cascading trophic interactions and lake productivity. Bioscience 35: 634-639

Cloern JE (1987) Turbidity as a control on phytoplankton biomass and productivity in estuaries. Cont Shelf Res 7: $1367-1381$

Eppley RW (1972) Temperature and phytoplankton growth in the sea. Fish Bull (Wash DC) 70:1063-1085

Evans GT, Paranjape MA (1992) Precision of estimates of phytoplankton growth and microzooplankton grazing when the functional response of grazers may be nonlinear. Mar Ecol Prog Ser 80:285-290

Froneman PW, McQuaid CD (1997) Preliminary investigation of the ecological role of microzooplankton in the Kariega Estuary, South Africa. Estuar Coast Shelf Sci 45:689-695 
Frost BW (1993) A modelling study of processes regulating plankton standing stock and production in the open subartic Pacific Ocean. Prog Oceanogr 32:17-56

Hobbie JE, Daley RJ, Jasper S (1977) Use of Nuclepore filters for counting bacteria by fluorescence microscopy. Appl Environ Microbiol 33:1225-1228

Gallegos CL (1989) Microzooplankton grazing on phytoplankton in the Rhode River estuary, Maryland: nonlinear feeding kinetics. Mar Ecol Prog Ser 57:23-33

Guillard RRL, Hargraves PE (1993) Stichochrysis immobilis is a diatom, not a chrysophyte. Phycologia 32:234-236

Kamiyama T (1994) The impact of grazing by microzooplankton in northern Hiroshima Bay, the Seto Inland Sea, Japan. Mar Biol 119:77-88

Kana TM, Glibert PM (1987) Effect of irradiances up to 2000 $\mu \mathrm{E} \mathrm{m} \mathrm{m}^{-2} \mathrm{~s}^{-1}$ on marine Synechococcus WH7803. I. Growth, pigmentation, and cell composition. Deep-Sea Res 34: 479-495

Kautsky N, Kautsky H, Kautsky U, Waern M (1986) Decreased depth penetration of Fucus vesiculosus (L.) since the 1940s indicates eutrophication of the Baltic Sea. Mar Ecol Prog Ser 28:1-8

Kiorboe T (1998) Population regulation and role of mesozooplankton in shaping marine pelagic food webs. Hydrobiologia 363:13-27

Landry MR, Hassett RP (1982) Estimating the grazing impact of marine micro-zooplankton. Mar Biol 67:283-288

Landry MR, Kirshtein J, Constantinou J (1995) A refined dilution technique for measuring the community grazing impact of microzooplankton, with experimental tests in the central equatorial Pacific. Mar Ecol Prog Ser 120: $53-63$

Landry MR, Brown SL, Campbell L, Constantinou J, Liu H (1998) Spatial patterns in phytoplankton growth and microzooplankton grazing in the Arabian Sea during monsoon forcing. Deep-Sea Res II 45:2353-2368

Lessard EJ, Murrell MC (1998) Microzooplankton herbivory and phytoplankton growth in the northwestern Sargasso Sea. Aquat Microb Ecol 16:173-188

Li W (1998) Annual average abundance of heterotrophic bacteria and Synechococcus in surface ocean waters. Limnol Oceanogr 43:1746-1753

Liu H, Dagg M (2003) Interactions between nutrients, phytoplankton growth, and microzooplankton grazing in the plume of the Mississippi River. Mar Ecol Prog Ser 258: 31-42

Lonsdale DJ, Cosper EM, Doall M (1996a) Effects of zooplankton grazing on phytoplankton size-structure and biomass in the lower Hudson River Estuary. Estuaries 19: 874-889

Lonsdale DC, Cosper EM, Kim WS, Doall M, Divadeenam A, Jonasdottir SH (1996b) Food web interactions in the plankton of Long Island bays, with preliminary observations on brown tide effects. Mar Ecol Prog Ser 134: $247-263$

Michael HJ, Boyle KJ, Bouchard R (1996) Water quality affects property prices: a case study of selected Maine lakes. Miscellaneous Report 398. Maine Agricultural

Editorial responsibility: Robert Sanders,

Philadelphia, Pennsylvania, USA and Forest Experimental Station, University of Maine, Walpole, ME

Moore L, Goericke R, Chisholm S (1995) Comparative physiology of Synechococcus and Prochlorococcus: influence of light and temperature on growth, pigments, fluorescence, and absorptive properties. Mar Ecol Prog Ser 116: $259-275$

Murrell MC, Lores EM (2004) Phytoplankton and zooplankton seasonal dynamics in a subtropical estuary: importance of cyanobacteria. J Plankton Res 26:371-382

Murrell MC, Stanley RS, Lores EM, DiDonato GT, Flemer DA (2002) Linkage between microzooplankton grazing and phytoplankton-growth in a Gulf of Mexico estuary. Estuaries 25:19-29

National Research Council (2000) Clean coastal waters. National Academy Press, Washington, DC

Nejestgaard JC, Naustvoll LJ, Sazhin A (2001) Correcting for underestimation of microzooplankton grazing in bottle incubation experiments with mesozooplankton. Mar Ecol Prog Ser 221:59-75

Olinger LW, Rogers RG, Fore PL, Todd RL, Mullins BL, Bisterfield F, Wise LA (1975) Environmental and recovery studies of Escambia Bay and the Pensacola Bay system. US Environmental Protection Agency, Atlanta, GA

Orth RJ, Moore KA (1983) Chesapeake Bay: an unprecedented decline in submerged aquatic vegetation. Science 222:51-53

Paranjape MA (1987) Grazing by microzooplankton in the eastern Canadian Arctic in summer 1983. Mar Ecol Prog Ser 40:239-246

Pennock JR, Sharp JH (1994) Temporal alternation between light- and nutrient-limitation of phytoplankton production in a coastal plain estuary. Mar Ecol Prog Ser 111:275-288

Scott BD (1978) Phytoplankton distribution and light attenuation in Port Hacking Estuary. Aust J Mar Freshw Res 29: $31-44$

Sipura J, Lores E, Snyder RA (2003) Effect of copepods on estuarine microbial plankton in short-term microcosms. Aquat Microb Ecol 33:181-190

Strom SL, Strom MW (1996) Microplankton growth, grazing, and community structure in the northern Gulf of Mexico. Mar Ecol Prog Ser 130:229-240

Strickland JDH, Parsons TR (1972) A practical handbook of seawater analyses. Fisheries Research Board of Canada, Ottawa

Tilzer MM (1988) Secchi disk-chlorophyll relationships in a lake with highly variable phytoplankton biomass. Hydrobiologia 162:163-171

Yentsch CS, Phinney DA (1985a) Spectral fluorescence: an ataxonomic tool for studying the structure of phytoplankton populations. J Plankton Res 7:617-632

Yentsch CS, Phinney DA (1985b) The use of fluorescence spectral signatures of marine phytoplankton. In: Zirino A (ed) Mapping strategies in chemical oceanography. Advances in Chemistry Series No. 209. American Chemical Society, Washington, DC

Zar JH (1974) Biostatistical analysis. Prentice-Hall, Englewood Cliffs, NJ

Submitted: May 11, 2004; Accepted: October 26, 2004

Proofs received from author: January 25, 2005 